\title{
AZ ÉN BoLOGNA-VÍZIÓM
}

\section{TRENCSÉNYI LÁSZLÓ}

az Eötvös Loránd Tudományegyetem Pedagógiai és Pszichológiai Karának

tanszékvezető habilitált egyetemi docense

trenyo@dpg.hu

Hogy miért érzem benne jól magam? Hogy miért vállalom? Állok ki érte? Miközben ezer gondját naponta vergődöm végig diákjaimmal? Elsősorban persze a BAképzés nehézségei jelentenek szakmai-lelkiismereti gondot. Nálunk, az ELTE-n is „elöállítunk” (segítünk nekik létrejönni) valóban kompetens, olykor elkötelezett fiatal „emberjavításra” készülő értelmiségit, $\mathrm{s}$ aztán a munkaerőpiac meg sajnálkozik vagy nevet a markába: neki ezekre a márkás munkadarabokra pedig se pénze, se szüksége.... A tehetséges BA-hallgatót vagy azért éri csalódás, mert a „sors nem nyitott nekik tért" (Petőfit idézvén), vagy azért, mert továbbtanulási ambícióihoz már nem méretezett a keretszám. Nem győzöm hangsúlyozni, ez nagy gond, óriási gond! De nem a „bolognai tanárképzés” gondja - bárki bármit is mond. Szóval miért szeretem a bolognai tanárképzést? Vegyük sorra.

Szerencsés megoldásnak tartom, hogy nem frissen érettségizve - jóformán nagykamaszként 18-19 évesen kell sorsdöntő - a régi rend szerint szinte változtathatatlan pályaválasztási döntést hozniuk a leendő hallgatóknak. Pályaválasztási döntést? Csudát! Tanulási irányválasztást. Mint megtapasztaltuk: a közhangulat szerint ugyanolyan szak tanárának jelentkezni kisebb erőfeszítést igényelt, mint ugyanolyan szak „tudósának”. (Tudom: a pedagógusdinasztiák esetében ez nem így van - magam is ebben nőttem -, a „bölcsőben”, legalábbis a cserkész-, vagy úttörőcsapatban eldőlt a kérdés: a családi tradícó folytatása - akárhogyan és akárhol. De ez azért kisebbség, ugye tudjuk? Miközben fontos kisebbség, ezt is tudjuk.)

De azt is tudjuk, hogy a pedagógusképzésben való elindulás, értelmiségivé nevelkedés-emelkedés jellegzetes elsőgenerációs stratégia. Félreértés ne legyen: irgalmatlanul szüksége van az iskola világának - ma különösen - elsőgenerációs értelmiségiekre (akiknek még sajátélmény a szegénysor, a külváros, a - félve merem leírni a putri. De azt is tudom, hogy e világ, e hozomány túlsúlya a pedagógusvilágban nem teljesítményfokozó tényező, az elsőgenerációs értelmiségi/pedagógus maga is érzékeny nevelőkre, mentorokra szorul, jóformán egész élete azzal telik, hogy hátrányait ledolgozza, hogy gyakorta észlelt kisebbségi érzését ne a növendékein torolja meg, hogy ne féljen egy-egy tehetséges tanuló nehezebb kérdéseitől.

A Bologna-folyamat két szintje e kérdést, ha nem is oldja meg: ,kezeli”: Miért mondom ezt? Mert a 21-22 éves ifjú mégiscsak inkább tehető felelőssé pályavá- 
lasztásáért, 3 év alatt megmutatkozik, hogy a nehéz feladattal, Toldiként a „kor jármának legyőzésével" miként birkózik, milyen etikai tartás vezeti a pályához. (Szemben a „régi rendszerrel”, amikor tehát sokan végzetesen a „könnyebb” [könynyebbnek hitt] föiskolán haladtak, mert az egyetem „fura uraitól” már a felvételkor eltanácsolódtak.)

Tehát a kétszintes képzést az esélyegyenlőség értékeire figyelve is biztonságosabbnak, a kontraszelekciót elkerülhetőnek, a szelekciót mégiscsak némi önkontrollal (önszelekcióval?) gondozhatóbbnak tartom. Ennyit a társadalmi mobilitási problémához.

De térjünk vissza a tanárrá válás kísérletéhez. Ahhoz a bizonyos 21-22 éves ifjú emberhez. Aki felelösebb $-\mathrm{s}$ a pályához igazodóbb - döntést tud hozni, vállalja-e a tanári mesterséggel járó gondokat és örömöket, feladatokat és kihívásokat. (Nyilván a MA-tanárképzés , ,anyaga” - kompetenciastruktúrája - is hozzájárul ahhoz, hogy a pedagógusmesterségnek napjaink elvárásaihoz [a gyerekkép, a tanuláskép, a társadalomkép - s mi még? - változásaihoz] jobban igazodjék az az összetevője, amit a közvetítés-értékhez segítés szakmai összetevőinek [ama bizonyos pedagógiai-pszichológiai modulnak] tekintünk. ${ }^{1}$ De erről most nem szólnék, mert ha Bologna „vitapartnereinek" azt mondjuk, hogy jóformán még el sem kezdődött, tessék kivárni az első tapasztalatokat a kritikával, akkor ez a türelem rám is vonatkozik.)

A 'tízkredites' funkcióiról szólnék néhány szót. Ugye, ezek azok a kurzusok, melyek egyfelöl (csaknem kemény) feltételei a tanárszakra való jelentkezésnek, másfelöl a BA képzésre járó hallgatók elkötelezettség nélkül kóstolgathatják szakmánkat, a pedagógia mesterségét. És ez nagyon jó! Főként, ha valóban tudjuk érvényesíteni pályaismereti-önismereti funkcióit, s nem látunk neki - adjad uramisten mi is a „bonszai”-kiképzésnek (ahogyan ezt néhány tekintélyes tudomány saját BA-jával teszi ijedtében és szerepzavarában).

Tapasztalataim a „Pedagógiai tapasztalatok és nézetek” elnevezésü, mindössze egy kreditet érő - szöveges értékeléssel záruló - 30 órás kurzusról vannak. Úgy érzem, optimálisan betölti ezt az orientációs, kölcsönösen „kóstolgató” funkciót. S - tisztesség ne essék szólván - a „tömegképzés” keretei közt is módot ad intenzív személyközi kapcsolatra (egyetemünk bölcs döntéssel 15 fös csoportokat engedélyezett e kurzusra - itt bizony lélektől-lélekig vezető folyamatokról van szó. S nincs kárbaveszett kapacitás. Hiszen az is eredmény, ha valaki úgy összegzi a kurzuson „pedagógiai tapasztalatait és nézeteit”, hogy megérti: nem az ő útja. De hát az is eredmény, ha valaki meg valóban elköteleződik - legalább a tájékozódásban motivált lesz. (Megjegyzem egyébként: egyáltalán nem kárbaveszett kapacitás senki esetében sem: ennyi nevelési kultúrát érdemes „beruházni” nem csupán a leendő

\footnotetext{
${ }^{1}$ Az személyes megjegyzésem csak, hogy (egyébként a képzés valóságos tartalmaihoz igazítva) e modul elnevezése se csak a pedagógia - idörendben, történetileg első - empirikus „szolgálóját” nevesítse, de fiatalabb társait, a szociológiát, kulturális antropológiát is. De ez „Bologna védelmében” ma részletkérdés.
} 
értelmiségibe, de a leendő anyának, apának, keresztanyának, főnöknek, közéleti embernek sem árt.)

Csak néhány idézet a reflektáló-önreflektáló hallgatói portfóliókból: ${ }^{2}$

„Hozott anyagból dolgoztunk, és meglepő, hogy milyen hatékony volt ez a munka... Újrajátszottuk a történeteinket, és rájöhettünk arra is, hogy adott szituációban mit rontottunk el. A helyzeteket félig tanárként, félig diákként vizsgáltuk." (N. B. magyar szakos)

„Tanulságos volt különböző karakterek bőrébe bújni a szituációkban. Hiszen így jöhettünk rá igazán, hogy adott helyzetben mit csinálnánk jobban." (B. A. magyar szakos)

„Szerettem ezt az órát, bár tény, sokszor féltem a szerepléstől... Öszintén szólva ettől a kis véleménynyilvánítástól is kivert a víz, hiszen régen írtam én már 9 oldalakat - kivéve, ha egyenletelemzésekről volt szó. Megpróbáltam ezzel is megbirkózni." (B. A. matematika szakos)

„Amikor saját történetemet adtuk elö, én játszottam a tanárnőmet. Elég furcsa volt. Öt mindig mint egyfajta kívülállót láttam, nem képzeltem bele magam az ő helyébe. A játék során rájöttem, hogy igazából milyen összetett dolog tanárnak lenni. ... A kis darabok után másképp nézek a tanárokra. ... A történetek, valamint az azt követő beszélgetések után sok mindent másképp látok, sok mindenben megerősítést találtam. Legfőbb tanulságnak azt tartom, hogy a tanár személyiségét eszközként alkalmazhatja. Ez alapvetően újdonság számomra, hiszen magamban gondoltam ilyesmikre, amikor valakit jó tanárnak tartottam, ott ezt a jól kihasznált személyiséget is fontosnak éreztem, de így kimondva még nem, s ez... megnyugtatott. Mindazonáltal én magamról úgy gondolom, még nem teljesen vagyok erre képes, de némi gyakorlat és tanulás után, azt hiszem, elsajátíthatom.” (D. D. nyelvszakos)

„Azzal a megnyugtató felfedezéssel párhuzamosan, hogy tudomásul vehettem: ezen az egyetemen humánus, hozzáértő pedagógusok képzése folyik, akik nem csak az elméletekkel vannak tisztában, hanem a mindennapi iskolai életben is megállják helyüket, azzal is szembesülnöm kellett, hogy bizony a pedagógusi pályára lépő hallgatónak a későbbiekben a helyzetgyakorlatokban eljátszott problémákkal mind-mind meg kell küzdenie. Sőt! Ennél természetesen még sokkal többel. Úgy érzem, hogy egy elhivatottságot érző hallgató ilyenkor vágyat érez arra, hogy ezeket a problémákat jól meg tudja oldani. Bennem azonban egy hatalmas kétely fogalmazódott meg: hogyan tudnék

\footnotetext{
${ }^{2}$ Az alkalmazott módszert magát is természetesen fontosnak tartom. „Békeidőben” majd le is fogom írni, elemezni, bemutatni, hiszen „sokszorosítható”. A rövid lényege az, hogy a hallgatók az első órákon írásban megörökített saját iskolai történetei képezik a drámajátékos improvizációkban (szakértői játékban) érvényesülő reflektált, olykor több változatban is eljátszott szituációkra épülő elemzések alapját.
} 
mindezekkel megbirkózni. S ezután a döbbenet: talán sikerülne, de nem szeretném elvállalni. Ezek után talán nem meglepö, hogy végül azt a döntést hoztam, hogy nem választom a tanári pályát. Úgy érzem azonban, hogy ez a döntés nem valamiféle szomorú lemondás. Inkább egy jó döntésnek vélem, amellyel magam is megkímélem számos nehézségtől, és természetesen mindazokat a diákokat, akiket nem fogok tanítani." (K. SZ. pszichológia szakos)

Meggyőző volt? 